\title{
A Chinese family with Noonan syndrome caused by a heterozygous variant in LZTR1: a case report and literature review
}

\author{
Xiu Zhao', Zhuoguang Li', Li Wang ${ }^{1}$, Zhangzhang Lan², Feifei Lin³ ${ }^{3}$ Wenyong Zhang ${ }^{2}$ and Zhe Su ${ }^{1 *}$ (D)
}

\begin{abstract}
Background: Noonan syndrome is an inherited disease involving multiple systems. More than 15 related genes have been discovered, among which LZTR1 was discovered recently. However, the pathogenesis and inheritance pattern of LZTR1 in Noonan syndrome have not yet been elucidated.

Case presentation: We herein describe a family with LZTR1-related Noonan syndrome. In our study, the proband, sister, mother, maternal aunt and grandmother and female cousin showed the typical or atypical features of Noonan syndrome. Only 3 patients underwent the whole-exome sequencing analysis and results showed that the proband as well as her sister inherited the same heterozygous LZTR1 variant (c.1149+1G > T) from their affected mother. Moreover, the proband accompanied by growth hormone deficiency without other associated variants.

Conclusion: In a Chinese family with Noonan syndrome, we find that the c.1149+1G > T variant in LZTR1 gene shows a different autosomal dominant inheritance from previous reports, which changes our understanding of its inheritance and improves our understanding of Noonan syndrome.
\end{abstract}

Keywords: Noonan syndrome, LZTR1, Autosomal dominant, Growth hormone deficiency

\section{Background}

Noonan syndrome (OMIM 163950), with an estimated incidence of every 1000-2500 live births, is an autosomal dominant (AD) or recessive (AR) disorder that involves multiple systems with high heterogeneity [1]. To date, more than 15 genes associated with Noonan syndrome have been reported [2, 3], among which, variants of LZTR1 have been newly associated with the etiology of Noonan syndrome since 2014 [4-6]. LZTR1 (OMIM 600574) is the abbreviation for the leucine zipper-like transcriptional regulator 1 gene and is located on 22q11.2. So far, less than 50 cases of Noonan syndrome have been associated with LZTR1 variants [2, 4, 5, 7-10], making its genetic pattern not well understood. For

\footnotetext{
*Correspondence: su_zhe@126.com

'Endocrinology Department, Shenzhen Children's Hospital, 7019\# Yitian Road, Futian District, Shenzhen 518038, Guangdong Province, China

Full list of author information is available at the end of the article
}

example, the c. $1149+1 \mathrm{G}>\mathrm{T}$ variant in LZTR1 gene was characterized by AR inheritance in the previous literature involving 3 patients with Noonan syndrome [7, 8, 11]. However, in our patients, we find that the facts are not exactly as reported in the previous literature. Here we report a Chinese family with Noonan Syndrome caused by a heterozygous variant in LZTR1, which will change the previous understanding of LZTR1 inheritance and improve our understanding of Noonan Syndrome.

\section{Methods and materials \\ Clinical reports}

Patient 1 The proband (Fig. 1, III-3), a 6.6-year-old girl, was admitted to our hospital because of short stature. As the first child of nonconsanguineous parents, she was born at 41 weeks of gestation via vaginal delivery, whose birth weight and length were $1800 \mathrm{~g}\left(<\mathrm{P} 3^{\text {rd }}\right)$ and $47 \mathrm{~cm}$ $\left(<\mathrm{P} 3^{\text {rd }}\right)$, respectively. She showed significant growth 


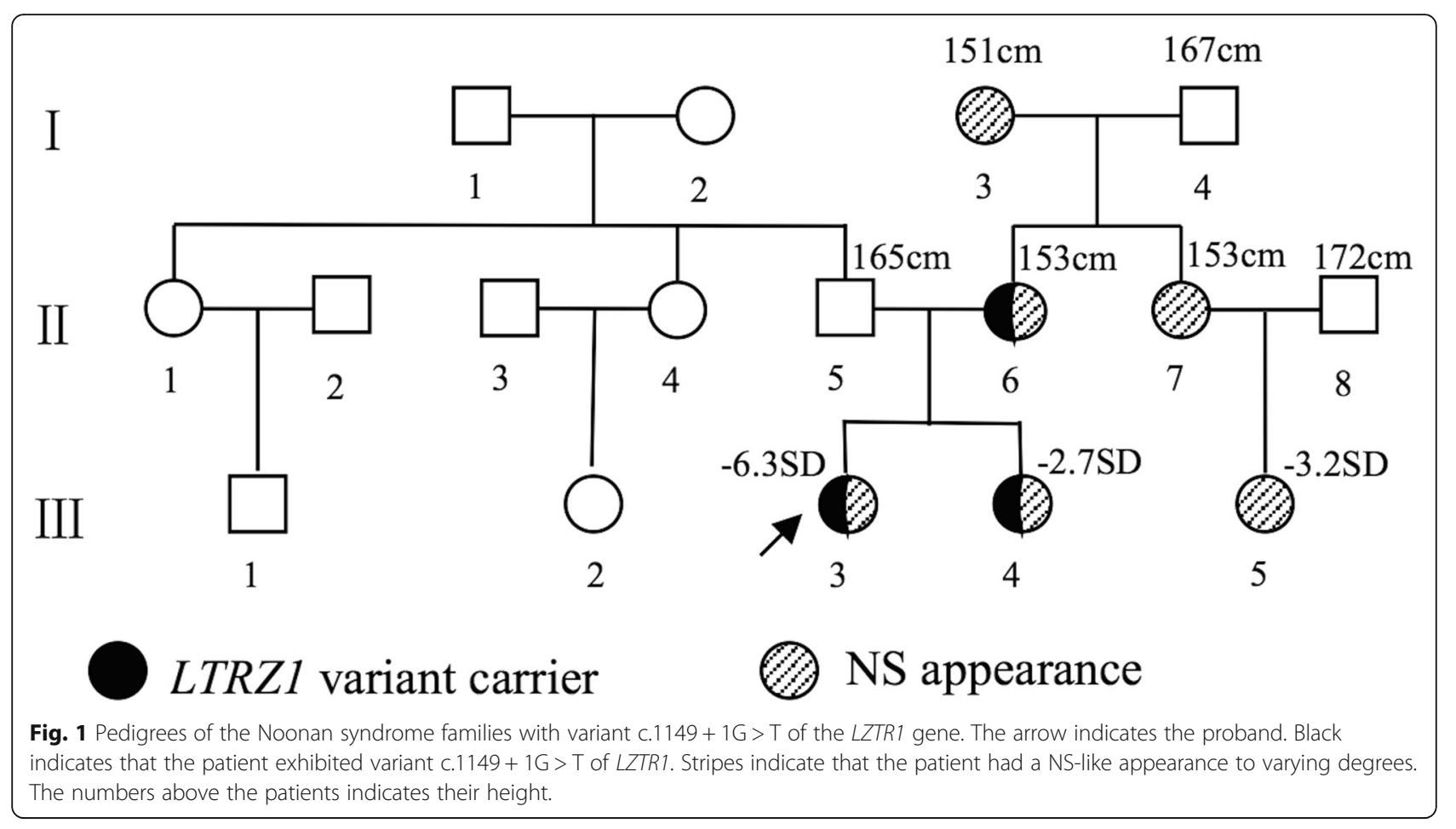

retardation since the newborn stage, and now her height, weight and body mass index (BMI) were $90.5 \mathrm{~m}(-6.3$ $\mathrm{SD}), 11 \mathrm{~kg}(-4.9 \mathrm{SD})$ and $13.4 \mathrm{~kg} / \mathrm{m}^{2}$ (P10-25th), respectively. Her ratios of arm span/height and sitting height/height were $0.92(-2 \mathrm{SD})$ and $0.58(+3 \mathrm{SD})$ according to the standard reference values [12]. Her psychomotor development was mildly delayed.

Physical examination: She showed the following typical features of Noonan syndrome (Fig. 2): hypertelorism; downslanting palpebral fissures; epicanthal folds; low-set, oval-shaped, posteriorly rotated ears with a thick helix; a short broad nose with a depressed root and full tip; a deeply grooved and long philtrum; high and wide peaks of the vermilion; a highly arched palate; micrognathia; a short neck; cubitus valgus; scoliosis; café au lait spots; and mild hypertrichosis. She also presented with squinting, refractive errors and nystagmus.

Auxiliary examination: The IGF-1 level was $61 \mu \mathrm{g} / \mathrm{L}$ $(-1.9 \mathrm{SD})$ and growth hormone $(\mathrm{GH})$ stimulation test (insulin and levodopa stimulation test) showed that $\mathrm{GH}$ peak was $5.54 \mathrm{ng} / \mathrm{mL}$ (cut-off value: $<7 \mathrm{ng} / \mathrm{mL}$ ). The electrocardiogram test showed frequent premature ventricular beats (the second and third rhythms), X-rays and MRI of the spine showed hemivertebral deformity of the third thoracic vertebra and scoliosis (Cobb's angle = $28^{\circ}$ ), and her bone age was 5.5 years old. In addition, hormone levels of the adrenal gland, thyroid gland and

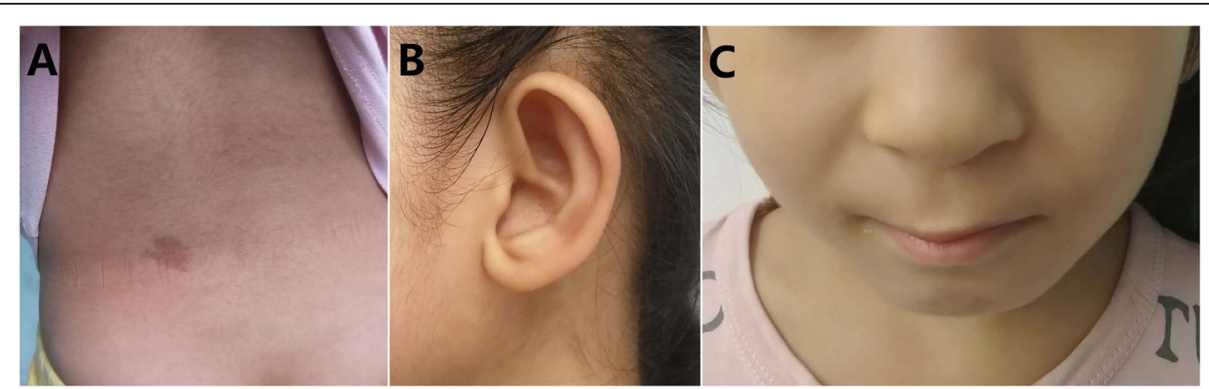

Fig. 2 Clinical images showing Noonan-like features in the proband, who provided consents. a Café au lait spots and mild hypertrichosis. b Lowset, oval-shaped, posteriorly rotated ears with a thick helix. c Short broad nose with a depressed root and full tip, deeply grooved and long philtrum, and high and wide peaks of the vermilion 
gonad were normal; the tumor markers (includes AFP, HCG and CEA) were also negative. No abnormalities were found during the ultrasound examination of the heart, liver, kidneys, uterus or ovaries, so did the MRI of the craniocerebrum. Besides, her karyotype was 46, XX.

According to the clinical manifestation and laboratory tests, she was diagnosed as Noonan syndrome with GH deficiency clinically [13]. Due to her serious scoliosis and hemivertebral deformity, recombined human $\mathrm{GH}$ treatment was not recommended.

Patient 2 (Fig. 1, III-4) was the younger sister of the proband. Her birth weight and height were $3000 \mathrm{~g}$ (P50th) and $49 \mathrm{~cm}$ (P25th), respectively, with a gestational age of 38 weeks. Her height and weight were 82.5 $\mathrm{cm}(-2.7 \mathrm{SD})$ and $10.7 \mathrm{~kg}(-1.8 \mathrm{SD})$ at the age of 2.5 years. She had similar facial appearance to patient 1 . She had no skeletal abnormities except for pectus carinatum. She didn't show mental retardation, nor did she have any diseases of the heart and genitourinary system. The patient was also diagnosed as Noonan syndrome clinically (Fig. 3).

Suspected patient 3 (Fig. 1, II-6) was the mother of patients 1 and 2 . She was 27 years old, and her height was $153 \mathrm{~cm}(-1.7 \mathrm{SD})$. She showed the mild phenotype of Noonan syndrome: hypertelorism; downslanting palpebral fissures; low-set, oval-shaped, posteriorly rotated ears with a thick helix; a highly arched palate; and prominent nasolabial folds. She didn't show mental retardation, nor did she have any diseases of the heart, genitourinary system and skeletal system (Fig. 3).

Suspected patient 4 (Fig. 1, I-3) and suspected patient 5 (Fig. 1, II-7) were the mother and younger sister of patient 3, respectively. They had appearance features similar to those of patient 3. Their heights were $151 \mathrm{~cm}(-1.9 \mathrm{SD})$ and $153 \mathrm{~cm}(-1.7 \mathrm{SD})$, respectively.

Suspected patient 6 (Fig. 1, III-5) was the daughter of patient 5 . At the age of 3 years, she showed a short stature $(84.3 \mathrm{~cm},-3.2 \mathrm{SD})$ and similar facial appearance to patients 1 . She didn't show mental retardation, nor did she have any diseases of the heart, genitourinary system and skeletal system.

\section{Whole exome sequencing}

After obtaining the informed consent from her family, whole exome sequencing (WES) analysis was performed on the proband and her family. Genomic library was built using a standard library construction kit, and exons were captured using the target sequence capture probe. All of the exons (including the $50 \mathrm{bp}$ flanking piece on either side) were captured in a single reaction, and genes related to the RASopathies were thus considered. The average sequencing depth, average coverage and 10X coverage (coverage of sites with depth greater than 10) in the target region were 153.02X, 99.43 and $96.28 \%$, respectively. A standard bioinformatics pipeline was utilized for variant identification with the help of Genome Analysis Toolkit (GATK) [14] software following the best practice guidelines recommended by the GATK $[15,16]$. Candidate variants were retained as follows: (1) rare variants with a minor allele frequency of $<$ $1 \%$ in the ExAC, dbSNP, 1000 Genomes, gnomAD and local databases, and (2) functional variants including frameshift, splice, nonsense, missense and synonymous

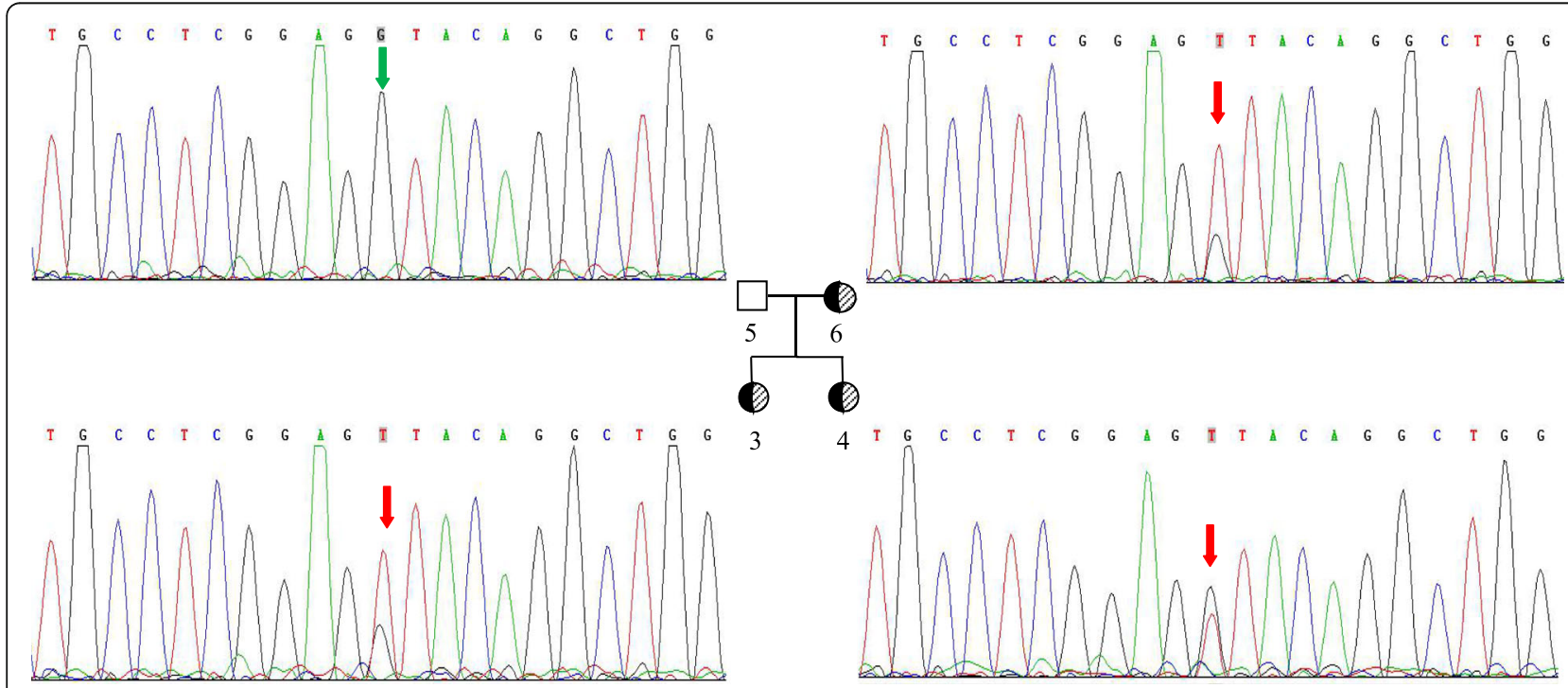

Fig. 3 Sanger validation of mutation c. $1149+1 G>T$ of the $L Z T R 1$ gene in the proband's family. Variant c. $1149+1 G>T$ is shown in red. Absence of variant c. $1149+1 G>T$ is shown in green 
variants that can affect splicing. Then, we utilized a hypothesis-free approach to analyze all of the phenotyperelated genes. Nonetheless, exome sequencing is limited in detecting large deletions/duplications and deep intronic variants.

Eventually, we identified a heterozygous variant, c. $1149+1 G>T$, under accession number NM_006767.3 in the LZTR1 gene. No other variants were detected in the LZTR1 gene or in the other RASopathy genes in the proband. The proband did not harbor other mutations that have been associated with Noonan syndrome, GH deficiency, skeletal dysplasia and other genetic diseases. The splicing variant was ranked as "likely pathogenic" according to the 2015-ACMG Standards and Guidelines [17]. Sanger sequencing showed that the variant of the proband and her sister was inherited from the proband's mother, but her father without Noonan syndrome didn't carry the variant (Fig. 3). Unfortunately, patients 4-6 rejected the genetic analysis, and patients 2-6 didn't agree to share their photos.

\section{Discussion and conclusion}

Noonan syndrome is a genetic disease involving multiple systems, but as many as $25 \%$ of patients cannot get a clear genetic diagnosis, so its clinical diagnosis is equally important. The phenotype of Noonan syndrome is variable, including: short stature, congenital heart defects and/or cardiomyopathy, characteristic craniofacial dysmorphism and childhood benign or malignant tumors (such as leukemia and solid tumors). The diagnosis of Noonan syndrome mainly depends on its typical clinical manifestations [1, 18] The typical feature of Noonan syndrome is short stature, but some patients with Noonan syndrome have GH deficiency, as previous studies reported, 3 patients with Noonan syndrome have been diagnosed with GH deficiency [7, 8, 19]. In our study, the proband (III-3) was the fourth Noonan syndrome patient identified as having GH deficiency (Table 1).

To make accurate diagnoses quickly and effectively, we performed WES for molecular diagnoses and results showed that there was a heterozygous variant $(c .1149+1 G>T)$ in the LZTR1. Based on variant c. $1149+1 \mathrm{G}>\mathrm{T}$ in the LZTR1 gene segregating with Noonan syndrome-related phenotype in multiple affected family members, we speculated that the pedigree presented as dominant inheritance. Previous studies have demonstrated that $L Z T R 1$ variants can be acquired via $\mathrm{AR}$ or $\mathrm{AD}$ inheritance $[2,4,7,8,20]$. Variant c. $1149+1 \mathrm{G}>\mathrm{T}$ of LZTR1 gene was used to be reported as compound heterozygous variants in three patients with Noonan syndrome [7, 8, 11] (Table 2). Our patients had the Noonan syndrome phenotype and the heterozygous variant inherited in the $A D$ form. Additionally, the phenotype of Noonan syndrome ranges widely, from a normal appearance to typical features of Noonan syndrome. Families with AD NS exhibited vertical transmission of the phenotype with differential penetrance. Therefore, our report displayed the AD mode of hereditary Noonan syndrome with incomplete penetrance.

As we know, more than 15 gene variants are known to be involved in the etiology of Noonan syndrome. Pathogenic variants in the genes encoding proteins implicated in the RAS-MAPK signaling pathway are responsible for Noonan syndrome. These gene variants function upstream of the RAS/MAPK cascade or its regulation and they dysregulate the RAS/MAPK pathway, leading to sustained or excessive activation of ERK (which defines RASopathies) [1]. LZTR1-related Noonan syndrome was recently described. LZTR1 is a highly conserved gene and encodes a protein characterized by six tandemly arranged Kelch motifs at the $N$-terminus and two BTB/ POZ (broad complex, tramtrack and bric-a-brac/Pox virus and zinc finger) domains at the $C$-terminus. LZTR1 is an important regulator of the normal cell cycle and acts as a tumor suppressor. Additionally, LZTR1 has been found to be a conserved regulator of RAS ubiquitination and signaling [20-23].

In the current study, the variants of LZTR1 associated with Noonan syndrome were located in both the Kelch and BTB/POZ domains, and AD Noonan syndrome has been attributed to the Kelch motifs, especially Kelch motifs 1-4 [10, 20,23]. A new study showed that more than one RVxF motif is located between Kelch 5 and Kelch 6 in the LZTR1 gene. RVxF is a binding location of the protein phosphatase-1 (PP1) [23, 24]. Variant c.1149+ $1 G>T$ is located in Kelch domains $5-6$. This variant can cause splice abnormalities and produce truncated proteins and thus might influence the binding function of the RVxF motif and PP1. To our knowledge, more than $50 \%$ of phosphoserine/threonine dephosphorylation reactions are catalyzed by PP1 in mammalian cells [25]. PP1 multifunctionally interacts with dozens of polypeptides that function as substrates, inhibitors, chaperones, anchoring/scaffolding proteins, and substrate-specifiers $[24,26]$ and even those associated with heart physiology [27]. The proband's arrhythmia could be associated with the dysfunction of PP1.

In conclusion, we have described a rare condition of Noonan syndrome, caused by a heterozygous variant (c.1149+1G>T) in LZTR1, manifested as autosomal dominant inheritance, which is different from previous reports, which changes our understanding of the inheritance of LZTR1 gene and improves our understanding of Noonan syndrome. Besides, we find that patients with Noonan syndrome may suffer GH deficiency at the same time, which will help us to enrich the clinical spectrum of Noonan syndrome. 


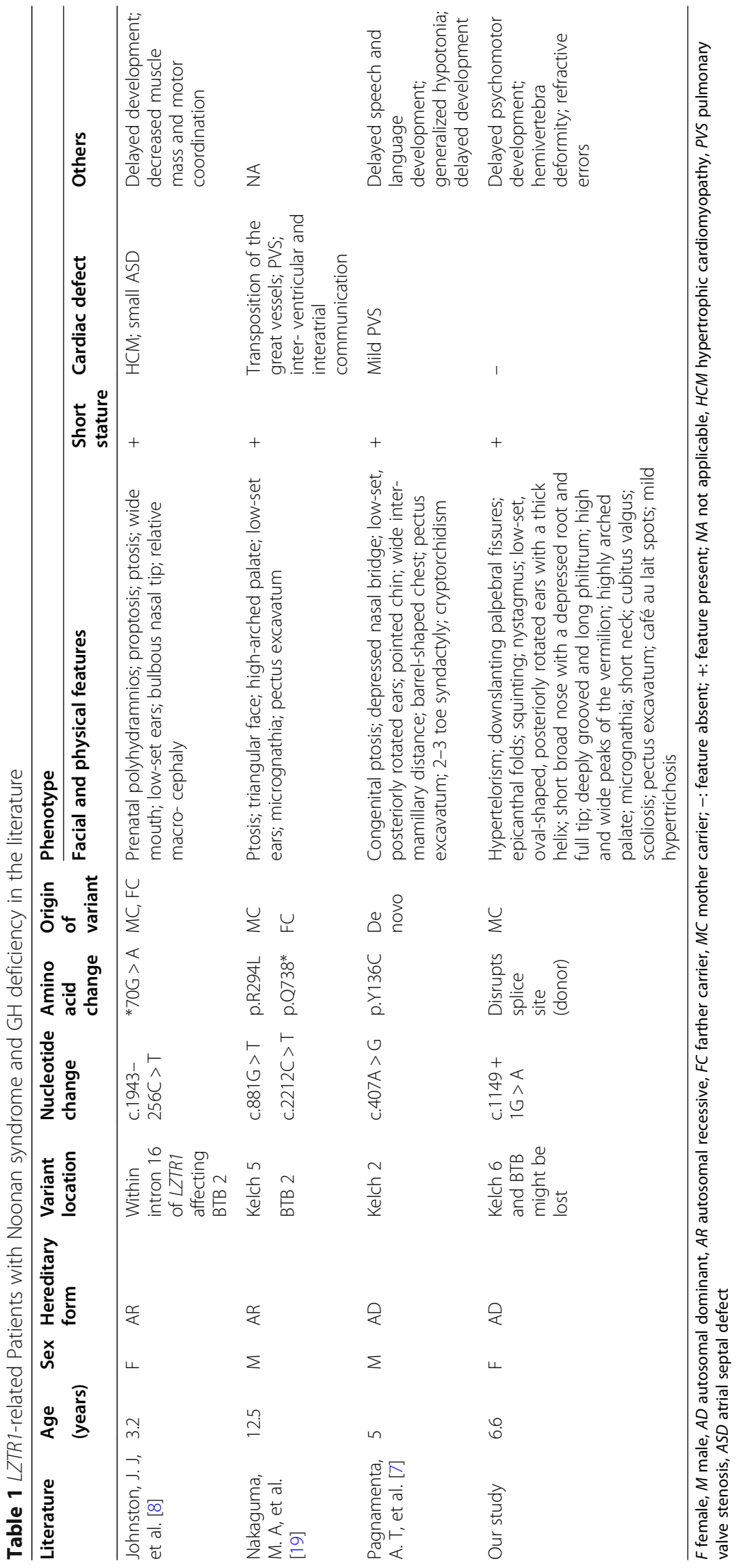




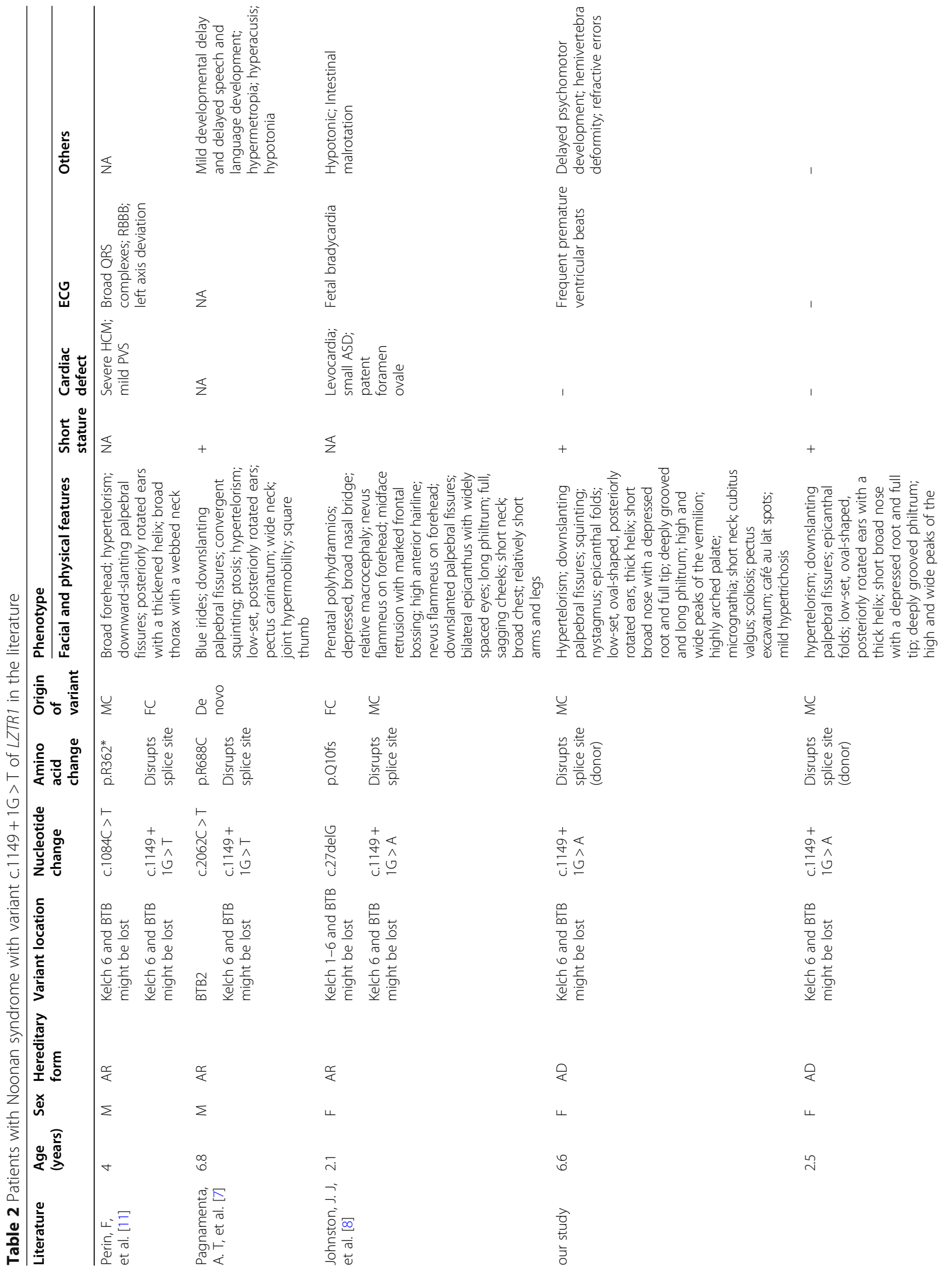




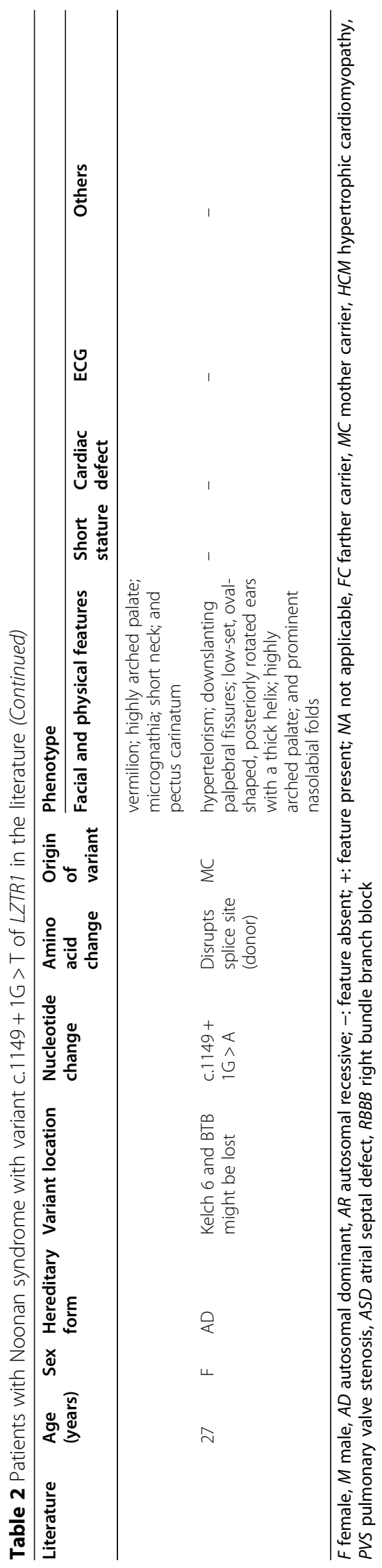




\section{Patients with Noonan syndrome should be tested for possible GH deficiency coincidence.}

\section{Abbreviations}

AD: Aautosomal dominant; AR: Autosomal recessive; GH: Growth hormone; LZTR1: Leucine zipper-like transcriptional regulator 1; PP1: Protein phosphatase-1

\section{Acknowledgments}

The authors would like to thank all the patients and their families for their participation in this study.

\section{Authors' contributions}

XZ contributed to the data collection, data interpretation and writing of the manuscript. ZS contributed to the study design and reviewed the report. ZGL contributed to the revision of the manuscript. LW contributed to the clinical data collection and data interpretation. FFL contributed to the imaging data collection and data interpretation. ZZL contributed to the gene variant interpretation. WYZ contributed to the gene-phenotype analysis. All authors have read and approved the manuscript.

\section{Funding}

This research was funded by Shenzhen Healthcare Research Project (SZLY2018014).

\section{Availability of data and materials}

The dataset analyzed in the current study is available from the corresponding author upon reasonable request.

\section{Ethics approval and consent to participate}

This study was approved by the ethics committee of Shenzhen Children's Hospital [No. 2020 (006)]. All of the subjects provided written informed consent in accordance with the Declaration of Helsinki.

\section{Consent for publication}

Written parental consent for publication was obtained on behalf of each of the children. Written consent for publication was obtained from all of the adults whose information is provided in this case report.

\section{Competing interests}

We declare that we have no financial and personal relationships with other people or organizations that could inappropriately influence our work, and there are no professional or other personal interests of any nature or type in any product, service and/or company that could be construed as influencing the position presented in, or the review of, the manuscript entitled.

\section{Author details}

${ }^{1}$ Endocrinology Department, Shenzhen Children's Hospital, 7019\# Yitian Road, Futian District, Shenzhen 518038, Guangdong Province, China. ${ }^{2}$ School of Medicine, Southern University of Science and Technology, Shenzhen 518055, Guangdong Province, China. ${ }^{3}$ Radiology Department, Shenzhen Children's Hospital, Shenzhen 518038, China.

Received: 25 June 2020 Accepted: 11 December 2020

\section{Published online: 06 January 2021}

\section{References}

1. Roberts AE, Allanson JE, Tartaglia M, Gelb BD. Noonan syndrome. Lancet. 2013;381(9863):333-42

2. Li X, Yao R, Tan X, Li N, Ding Y, Li J, Chang G, Chen Y, Ma L, Wang J, Fu L, Wang X. Molecular and phenotypic spectrum of Noonan syndrome in Chinese patients. Clin Genet. 2019;96(4):290-9.

3. Aoki Y, Niihori T, Inoue S, Matsubara Y. Recent advances in RASopathies. J Hum Genet. 2016;61(1):33-9.

4. Yamamoto GL, Aguena M, Gos M, Hung C, Pilch J, Fahiminiya S, Abramowicz A, Cristian I, Buscarilli M, Naslavsky MS, Malaquias AC, Zatz M, Bodamer O, Majewski J, Jorge AA, Pereira AC, Kim CA, Passos-Bueno MR, Bertola DR. Rare variants in SOS2 and LZTR1 are associated with Noonan syndrome. J Med Genet. 2015;52(6):413-21.

5. Chen PC, Yin J, Yu HW, Yuan T, Fernandez M, Yung CK, Trinh QM, Peltekova VD, Reid JG, Tworog-Dube E, Morgan MB, Muzny DM, Stein L, McPherson
JD, Roberts AE, Gibbs RA, Neel BG, Kucherlapati R. Next-generation sequencing identifies rare variants associated with Noonan syndrome. Proc Natl Acad Sci U S A. 2014;111(31):11473-8.

6. Chinton J, Huckstadt V, Mucciolo M, Lepri F, Novelli A, Gravina LP, Obregon MG. Providing more evidence on LZTR1 variants in Noonan syndrome patients. Am J Med Genet A. 2020;182(2):409-14.

7. Pagnamenta AT, Kaisaki PJ, Bennett F, Burkitt-Wright E, Martin HC, Ferla MP, Taylor JM, Gompertz L, Lahiri N, Tatton-Brown K, Newbury-Ecob R, Henderson A, Joss S, Weber A, Carmichael J, Turnpenny PD, McKee S, Forzano F, Ashraf T, Bradbury K, Shears D, Kini U, de Burca A, Blair E, Taylor $J C$, Stewart H. Delineation of dominant and recessive forms of LZTR1associated Noonan syndrome. Clin Genet. 2019;95(6):693-703.

8. Johnston JJ, van der Smagt JJ, Rosenfeld JA, Pagnamenta AT, Alswaid A, Baker EH, Blair E, Borck G, Brinkmann J, Craigen W, Dung VC, Emrick L, Everman DB, van Gassen KL, Gulsuner S, Harr MH, Jain M, Kuechler A, Leppig KA, McDonald-McGinn DM, Can N, Peleg A, Roeder ER, Rogers RC, Sagi-Dain L, Sapp JC, Schaffer AA, Schanze D, Stewart H, Taylor JC, Verbeek NE, Walkiewicz MA, Zackai EH, Zweier C, Zenker M, Lee B, Biesecker LG. Autosomal recessive Noonan syndrome associated with biallelic LZTR1 variants. Genet Med. 2018;20(10):1175-85.

9. El BI, Belhassan K, Moufid FZ, Iraqui HM, Bouguenouch L, Samri I, Atmani S, Ouldim K. Noonan syndrome-causing genes: molecular update and an assessment of the mutation rate. Int J Pediatr Adolesc Med. 2016:3(4):133-42.

10. Yamamoto GL, Aguena M, Gos M, Hung C, Pilch J, Fahiminiya S, Abramowicz A, Cristian I, Buscarilli M, Naslavsky MS, Malaquias AC, Zatz M, Bodamer O, Majewski J, Jorge AA, Pereira AC, Kim CA, Passos-Bueno MR, Bertola DR. Rare variants in SOS2 and LZTR1 are associated with Noonan syndrome. J Med Genet. 2015;52(6):413-21.

11. Perin F, Trujillo-Quintero JP, Jimenez-Jaimez J, Rodriguez-Vazquez DRM, Monserrat L, Tercedor L. Two novel cases of autosomal recessive Noonan syndrome associated with LZTR1 variants. Rev Esp Cardiol (Engl Ed). 2019; 72(11):978-80

12. Li-ping H, Zhe SU, Wei C, Hong-tao Ql, Li W, Li Z. Measurements of physical symmetry indexes for healthy children in Shenzhen aged $6 \sim 13$ years old. Chin J Child Health Care. 2017;25(8):815-7.

13. Allanson JE, Roberts AE. Noonan Syndrome; 1993.

14. McKenna A, Hanna M, Banks E, Sivachenko A, Cibulskis K, Kernytsky A, Garimella K, Altshuler D, Gabriel S, Daly M, DePristo MA. The genome analysis toolkit: a MapReduce framework for analyzing next-generation DNA sequencing data. Genome Res. 2010;20(9):1297-303.

15. DePristo MA, Banks E, Poplin R, Garimella KV, Maguire JR, Hartl C, Philippakis AA, Del AG, Rivas MA, Hanna M, McKenna A, Fennell TJ, Kernytsky AM, Sivachenko AY, Cibulskis K, Gabriel SB, Altshuler D, Daly MJ. A framework for variation discovery and genotyping using next-generation DNA sequencing data. Nat Genet. 2011;43(5):491-8.

16. Van der Auwera GA, Carneiro MO, Hartl C, Poplin R, Del AG, LevyMoonshine A, Jordan T, Shakir K, Roazen D, Thibault J, Banks E, Garimella KV, Altshuler D, Gabriel S, DePristo MA. From FastQ data to high confidence variant calls: the genome analysis toolkit best practices pipeline. Curr Protoc Bioinformatics. 2013:43:10-1.

17. Richards S, Aziz N, Bale S, Bick D, Das S, Gastier-Foster J, Grody WW, Hegde M, Lyon E, Spector E, Voelkerding K, Rehm HL. Standards and guidelines for the interpretation of sequence variants: a joint consensus recommendation of the American College of Medical Genetics and Genomics and the Association for Molecular Pathology. Genet Med. 2015;17(5):405-24.

18. Yart A, Edouard T. Noonan syndrome: an update on growth and development. Curr Opin Endocrinol Diabetes Obes. 2018;25(1):67-73.

19. Nakaguma M, Jorge A, Arnhold I. Noonan syndrome associated with growth hormone deficiency with biallelic LZTR1 variants. Genet Med. 2019;21(1):260.

20. Motta M, Fidan M, Bellacchio E, Pantaleoni F, Schneider-Heieck K, Coppola S, Borck G, Salviati L, Zenker M, Cirstea IC, Tartaglia M. Dominant Noonan syndrome-causing LZTR1 mutations specifically affect the Kelch domain substrate-recognition surface and enhance RAS-MAPK signaling. Hum Mol Genet. 2019;28(6):1007-22.

21. Steklov M, Pandolfi S, Baietti MF, Batiuk A, Carai P, Najm P, Zhang M, Jang $H_{\text {, }}$ Renzi F, Cai Y, Abbasi AL, Pastor T, De Troyer M, Simicek M, Radaelli E, Brems H, Legius E, Tavernier J, Gevaert K, Impens F, Messiaen L, Nussinov R, Heymans S, Eyckerman S, Sablina AA. Mutations in LZTR1 drive human disease by dysregulating RAS ubiquitination. Science. 2018;362(6419):1177-82. 
22. Aoki Y. RASopathies and hematologic abnormalities. Rinsho Ketsueki. 2015; 56(10):2240-7.

23. Umeki I, Niihori T, Abe T, Kanno SI, Okamoto N, Mizuno S, Kurosawa K, Nagasaki K, Yoshida M, Ohashi H, Inoue SI, Matsubara Y, Fujiwara I, Kure S, Aoki Y. Delineation of LZTR1 mutation-positive patients with Noonan syndrome and identification of LZTR1 binding to RAF1-PPP1CB complexes. Hum Genet. 2019;138(1):21-35.

24. Wakula P, Beullens M, Ceulemans H, Stalmans W, Bollen M. Degeneracy and function of the ubiquitous RVXF motif that mediates binding to protein phosphatase-1. J Biol Chem. 2003;278(21):18817-23.

25. Ferreira M, Beullens M, Bollen M, Van Eynde A. Functions and therapeutic potential of protein phosphatase 1: insights from mouse genetics. Biochim Biophys Acta Mol Cell Res. 2019;1866(1):16-30

26. Cohen PT. Protein phosphatase 1--targeted in many directions. J Cell Sci. 2002;115(Pt 2):241-56.

27. Liu R, Miller C, D'Annibale C, Vo K, Jacobs A. Differential localizations of protein phosphatase 1 isoforms determine their physiological function in the heart. Acta Biochim Biophys Sin Shanghai. 2019;51(3):323-30.

\section{Publisher's Note}

Springer Nature remains neutral with regard to jurisdictional claims in published maps and institutional affiliations.

Ready to submit your research? Choose BMC and benefit from:

- fast, convenient online submission

- thorough peer review by experienced researchers in your field

- rapid publication on acceptance

- support for research data, including large and complex data types

- gold Open Access which fosters wider collaboration and increased citations

- maximum visibility for your research: over $100 \mathrm{M}$ website views per year

At BMC, research is always in progress.

Learn more biomedcentral.com/submissions 